Article

\title{
Cytotoxic and Antibacterial Cembranoids from a South China Sea Soft Coral, Lobophytum sp.
}

\author{
Min Zhao ${ }^{1, \dagger}$, Jian Yin ${ }^{1, \dagger}$, Wei Jiang ${ }^{2}$, Minshan Ma $^{3}$, Xinxiang Lei ${ }^{3}$, Zheng Xiang ${ }^{1}$, \\ Jianyong Dong ${ }^{1}$, Kexin Huang ${ }^{1, *}$ and Pengcheng Yan ${ }^{1, *}$
}

1 School of Pharmacy, Wenzhou Medical College, Wenzhou 325035, China;

E-Mails: miniezhao@gmail.com (M.Z.); yinjian198708@gmail.com (J.Y.);

xzh007@126.com (Z.X.); jianyd@wzmc.edu.cn (J.D.)

2 College of Environmental Science and Engineering, Yangzhou University, Yangzhou 225127,

China; E-Mail: weijiang@yzu.edu.cn

3 Analytical and Testing Center, Wenzhou University, Wenzhou 325035, China;

E-Mails: youihj1023@gmail.com (M.M.); xxlei@wzu.edu.cn (X.L.)

$\dagger$ These authors contributed equally to this work.

* Authors to whom correspondence should be addressed; E-Mails: hkx@wzmc.edu.cn (K.H.); yanpc@wzmc.edu.cn (P.Y.); Tel.: +86-577-8668-9706 (K.H.); Fax: +86-577-8668-9706 (К.H.); Tel.: +86-577-8669-9229 (P.Y.); Fax: +86-577-8668-9983 (P.Y.).

Received: 28 February 2013; in revised form: 18 March 2013 / Accepted: 23 March 2013 /

Published: 3 April 2013

\begin{abstract}
Chemical examination of a South China Sea soft coral Lobophytum sp. led to the isolation of three new $\alpha$-methylene- $\gamma$-lactone-containing cembranoids, $\left(1 R^{*}, 3 R^{*}\right.$, $\left.4 R^{*}, 14 R^{*}, 7 E, 11 E\right)$-3,4-epoxycembra-7,11,15(17)-trien-16,14-olide (1), $\left(1 R^{*}, 7 S^{*}, 14 S^{*}, 3 E\right.$, $11 E)$-7-hydroperoxycembra-3,8(19),11,15(17)-tetraen-16,14-olide (2), and $\left(1 R^{*}, 7 S^{*}, 14 S^{*}\right.$, 3E,11E)-18-acetoxy-7-hydroperoxycembra-3,8(19),11,15(17)-tetraen-16,14-olide (3), along with eleven known analogues 4-14. The structures of the new compounds were elucidated through extensive spectroscopic analysis, including 1D and 2D NMR data. Compounds 1-3 exhibited moderate cytotoxic activity against the selected tumor cell lines. Moreover, 2 and $\mathbf{3}$ were found to be moderate inhibitors against the bacteria $S$. aureus and S. pneumoniae.
\end{abstract}

Keywords: soft coral; Lobophytum; cembranoids; cytotoxicity; antibacterial activity 


\section{Introduction}

Soft corals belonging to the genus Lobophytum (Alcyoniidae) have been shown to be a rich source of macrocyclic cembranoids and their cyclized derivatives [1-14], commonly described as defensive substances against predators such as other corals and fishes $[15,16]$. Some of these metabolites are of considerable interest and merit continuous attention due to their unique structures and significant biological activities, including anti-tumor, anti-viral, and anti-inflammatory properties [1-14]. As part of our ongoing research on bioactive marine natural products from Lobophytum corals of South China Sea [17-20], a Hainan soft coral, Lobophytum sp., has been chemically investigated based on the EtOAc extracts showing cytotoxicity against a panel of tumor cell lines including SGC7901 (human gastric carcinoma), A549 (human lung epithelial carcinoma), MCF7 (human breast carcinoma), HCT116 (human colonic carcinoma), and B16 (mouse melanoma). Chemical investigation resulted in the isolation of three new $\alpha$-methylene- $\gamma$-lactone-containing cembranoids (1-3), along with eleven known analogues 4-14 (Figure 1). The compounds isolated were evaluated for their cytotoxicity against selected tumor cell lines and antimicrobial activity. This paper deals with the isolation, structural elucidation, and bioactivity of these compounds.

Figure 1. Structures of compounds 1-14.
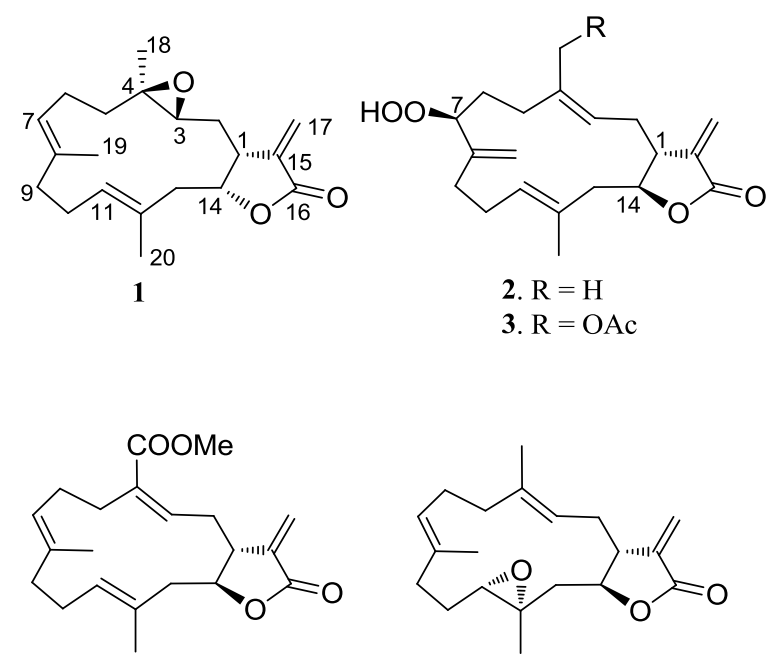

12
2. $\mathrm{R}=\mathrm{H}$

3. $\mathrm{R}=\mathrm{OAc}$

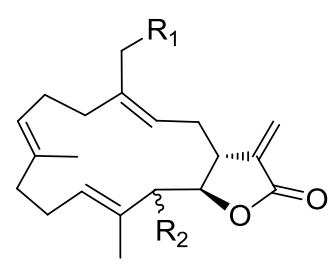

4. $\mathrm{R}_{1}=\mathrm{H}, \mathrm{R}_{2}=\mathrm{H}$

5. $\mathrm{R}_{1}=\mathrm{H}, \mathrm{R}_{2}=\alpha-\mathrm{OH}$

6. $\mathrm{R}_{1}=\mathrm{OAc}, \mathrm{R}_{2}=\beta-\mathrm{OH}$

7. $\mathrm{R}_{1}=\mathrm{OH}, \mathrm{R}_{2}=\mathrm{H}$

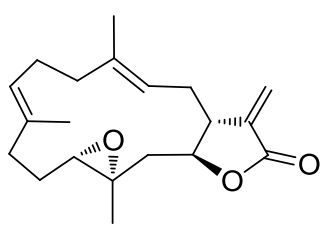

13

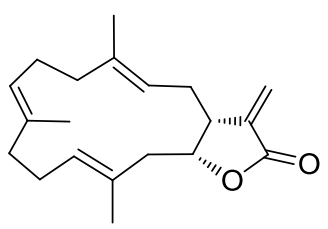

14

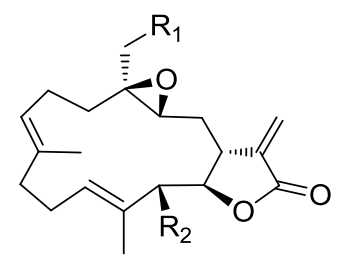

8. $R_{1}=H, R_{2}=H$

9. $\mathrm{R}_{1}=\mathrm{OAc}, \mathrm{R}_{2}=\mathrm{H}$

10. $R_{1}=O A c, R_{2}=O H$

11. $R_{1}=O A c, R_{2}=O A c$

\section{Results and Discussion}

Repeated column chromatography of the EtOAc fraction of the soft coral Lobophytum sp. resulted in the isolation and characterization of three new $\alpha$-methylene- $\gamma$-lactone-containing cembranoid diterpenes, namely $\left(1 R^{*}, 3 R^{*}, 4 R^{*}, 14 R^{*}, 7 E, 11 E\right)$-3,4-epoxycembra-7,11,15(17)-trien-16,14-olide (1), $\left(1 R^{*}, 7 S^{*}, 14 S^{*}, 3 E, 11 E\right)$-7-hydroperoxycembra-3,8(19),11,15(17)-tetraen-16,14-olide (2), and $\left(1 R^{*}, 7 S^{*}, 14 S^{*}, 3 E, 11 E\right)$-18-acetoxy-7-hydroperoxycembra-3,8(19),11,15(17)-tetraen-16,14-olide (3), along with eleven known related analogues 4-14. The structures of known compounds were identified by analysis of the NMR spectroscopic data and by comparison with those reported in the literature. They were identified as $\left(1 R^{*}, 14 S^{*}, 3 E, 7 E, 11 E\right)$-cembra-3,7,11,15(17)-tetraen-16,14-olide (4) [21], lobophytolide E (5) [22], durumolide B (6) [3], 13-dehydroxylpresinularolide B (7) [4], isolobophytolide 
(8) [21], lobolide (9) [23], 13-hydroxylobolide (10) [23], 13,18-diacetylsinularolide B (11) [4], lobophytolide B (12) [22], lobophytolide (13) [24], and lobophytolide A (14) [22], respectively. It is worthy to point out that 13,18-diacetylsinularolide B (11) [4], previously obtained by acetylation of 13-hydroxylobolide (10), is reported herein as a natural product for the first time.

Compound 1 was obtained as a colorless oil. The molecular formula, $\mathrm{C}_{20} \mathrm{H}_{28} \mathrm{O}_{3}$, consistent with seven degrees of unsaturation, was established by HRESIMS $m / z 317.2105[\mathrm{M}+\mathrm{H}]^{+}$(Calcd. 317.2111) and NMR data. The ${ }^{1} \mathrm{H}$ NMR spectrum of $\mathbf{1}$ exhibited the signals for three methyl groups including two olefinic methyls at $\delta_{\mathrm{H}} 1.74\left(3 \mathrm{H}, \mathrm{s}, \mathrm{H}_{3}-20\right)$ and $1.62\left(3 \mathrm{H}, \mathrm{s}, \mathrm{H}_{3}-19\right)$, and a tertiary methyl at $\delta_{\mathrm{H}} 1.27$ $\left(3 \mathrm{H}, \mathrm{s}, \mathrm{H}_{3}-18\right)$, while the ${ }^{13} \mathrm{C}$ NMR spectrum displayed 20 carbon resonances including a carbonyl and six olefinic carbons (Tables 1 and 2). IR absorptions at 1759 and $1660 \mathrm{~cm}^{-1}$ suggested the presence of an $\alpha$-methylene- $\gamma$-lactone group [3,21]. This assumption was further supported by the ${ }^{1} \mathrm{H}$ NMR signals at $\delta_{\mathrm{H}} 6.26(1 \mathrm{H}, \mathrm{d}, J=2.4 \mathrm{~Hz}, \mathrm{H}-17 \mathrm{a}), 5.52(1 \mathrm{H}, \mathrm{d}, J=2.4 \mathrm{~Hz}, \mathrm{H}-17 \mathrm{~b})$, and ${ }^{13} \mathrm{C} \mathrm{NMR}$ signals at $\delta_{\mathrm{C}}$ 169.9 (C, C-16), 138.3 (C, C-15), $120.8\left(\mathrm{CH}_{2}, \mathrm{C}-17\right), 77.1(\mathrm{CH}, \mathrm{C}-14)$, and 42.6 (CH, C-1). Four olefinic carbon signals at $\delta_{\mathrm{C}} 135.1(\mathrm{C}, \mathrm{C}-8), 130.1(\mathrm{CH}, \mathrm{C}-11), 129.6(\mathrm{C}, \mathrm{C}-12)$, and $122.3(\mathrm{CH}, \mathrm{C}-7)$, and two olefinic proton signals at $\delta_{\mathrm{H}} 5.11(1 \mathrm{H}, \mathrm{br} \mathrm{d}, J=9.0 \mathrm{~Hz}, \mathrm{H}-11)$ and $4.95(1 \mathrm{H}$, dd, $J=7.2,1.8 \mathrm{~Hz}, \mathrm{H}-7)$ were attributed to two trisubstituted double bonds. In addition, a trisubstituted epoxide was observed from carbon signals at $\delta_{\mathrm{C}} 62.3(\mathrm{CH}, \mathrm{C}-3)$ and $60.8(\mathrm{C}, \mathrm{C}-4)$, as well as an oxymethine proton at $\delta_{\mathrm{H}} 2.58(1 \mathrm{H}, \mathrm{dd}, J=10.2,1.2 \mathrm{~Hz}, \mathrm{H}-3)$. Six degrees of unsaturation, accounted for by the functional groups from seven in the molecule, suggested the remaining of a cyclic structure in 1. By interpretation of ${ }^{1} \mathrm{H}-{ }^{1} \mathrm{H}$ COSY correlations, three partial structures extending from $\mathrm{H}_{2}-13$ to $\mathrm{H}-3$, from $\mathrm{H}_{2}-5$ to $\mathrm{H}-7$, and from $\mathrm{H}_{2}-9$ to $\mathrm{H}-11$ were established. Moreover, the connectivities of these partial structures were established by HMBC correlations and revealed a 14-membered cembrane-type diterpenoid skeleton for 1 (Figure 2). The location of the epoxide at C-3 and C-4 was indicated by the HMBC correlations observed from $\mathrm{H}_{3}-18$ to $\mathrm{C}-3, \mathrm{C}-4$, and $\mathrm{C}-5$, while the locations of two double bonds at C-7/C-8 and C-11/C-12 were disclosed by the HMBC correlations from $\mathrm{H}_{3}-19$ to $\mathrm{C}-7, \mathrm{C}-8$, and $\mathrm{C}-9$, and from $\mathrm{H}_{3}-20$ to $\mathrm{C}-11, \mathrm{C}-12$, and $\mathrm{C}-13$. Thus, the gross structure of 1 was determined to be the same as isolobophytolide (8) [21], possessing an $\alpha$-methylene- $\gamma$-lactone ring fused to a 14-membered ring at C-1 and C-14. However, the diagnostic upfield shift of C-2 (-6.3 ppm) due to the presence of the $\gamma$-gauche effect was observed in $\mathbf{1}$, compared to $\mathbf{8}$, suggesting the lactone ring at $\mathrm{C}-1$ and $\mathrm{C}-14$ was $c i s$-fused. On the other hand, according to the general empirical rule that all cembrane diterpenes of known absolute configuration at C-1 reported from the order Alcyonacea belong to the $\alpha$ series [22], the configurations at C-1 and C-14 in 1 were assigned to be consistent with those of the co-occurring analogue lobophytolide A (14) [22]. The geometry of two double bonds at C-7/C-8 and C-11/C-12, and stereogenic centers at C-3 and C-4 were in agreement with those of isolobophytolide (8) on the basis of the similar NMR data. The stereochemistry of $\mathbf{1}$ as assigned above was further confirmed by the NOESY correlations (Figure 3) between H-1/H-14, H-1/H-3, H-3/H-5b, H-3/H-11, H-11/H-13b, and $\mathrm{H}-14 / \mathrm{H}-13 \mathrm{~b}$. Consequently, compound 1 was elucidated as a C-14 epimer of isolobophytolide (8), namely $\left(1 R^{*}, 3 R^{*}, 4 R^{*}, 14 R^{*}, 7 E, 11 E\right)-3,4$-epoxycembra-7,11,15(17)-trien-16,14-olide. 
Table 1. ${ }^{13} \mathrm{C}$ NMR data for compounds $\mathbf{1}-\mathbf{3}\left(\mathrm{CDCl}_{3}, 150 \mathrm{MHz}\right)$.

\begin{tabular}{|c|c|c|c|}
\hline No. & $1, \delta_{\mathrm{C}}$, type & $2, \delta_{\mathrm{C}}$, type & $3, \delta_{\mathrm{C}}$, type \\
\hline 1 & $42.6, \mathrm{CH}$ & $45.1, \mathrm{CH}$ & $45.0, \mathrm{CH}$ \\
\hline 2 & $26.0, \mathrm{CH}_{2}$ & $31.7, \mathrm{CH}_{2}$ & $32.1, \mathrm{CH}_{2}$ \\
\hline 3 & $62.3, \mathrm{CH}$ & $121.1, \mathrm{CH}$ & $127.4, \mathrm{CH}$ \\
\hline 4 & $60.8, \mathrm{C}$ & $137.2, \mathrm{C}$ & $135.9, \mathrm{C}$ \\
\hline 5 & $38.7, \mathrm{CH}_{2}$ & $34.7, \mathrm{CH}_{2}$ & $30.6, \mathrm{CH}_{2}$ \\
\hline 6 & $23.9, \mathrm{CH}_{2}$ & 28.6, $\mathrm{CH}_{2}$ & $28.6, \mathrm{CH}_{2}$ \\
\hline 7 & $122.3, \mathrm{CH}$ & $84.5, \mathrm{CH}$ & $84.2, \mathrm{CH}$ \\
\hline 8 & 135.1, C & $149.2, \mathrm{C}$ & 149.0, C \\
\hline 9 & $38.1, \mathrm{CH}_{2}$ & $33.5, \mathrm{CH}_{2}$ & $33.4, \mathrm{CH}_{2}$ \\
\hline 10 & $25.0, \mathrm{CH}_{2}$ & $28.4, \mathrm{CH}_{2}$ & $28.5, \mathrm{CH}_{2}$ \\
\hline 11 & $130.1, \mathrm{CH}$ & $128.0, \mathrm{CH}$ & $128.4, \mathrm{CH}$ \\
\hline 12 & $129.6, \mathrm{C}$ & $131.3, \mathrm{C}$ & $131.0, \mathrm{C}$ \\
\hline 13 & $42.7, \mathrm{CH}_{2}$ & $44.6, \mathrm{CH}_{2}$ & $44.7, \mathrm{CH}_{2}$ \\
\hline 14 & 77.1, CH & $81.7, \mathrm{CH}$ & $81.3, \mathrm{CH}$ \\
\hline 15 & $138.3, \mathrm{C}$ & $139.2, \mathrm{C}$ & 138.9, C \\
\hline 16 & $169.9, \mathrm{C}$ & $170.2, \mathrm{C}$ & 169.9, C \\
\hline 17 & $120.8, \mathrm{CH}_{2}$ & $121.9, \mathrm{CH}_{2}$ & $122.5, \mathrm{CH}_{2}$ \\
\hline 18 & $16.5, \mathrm{CH}_{3}$ & $16.3, \mathrm{CH}_{3}$ & $61.9, \mathrm{CH}_{2}$ \\
\hline 19 & $16.2, \mathrm{CH}_{3}$ & $111.6, \mathrm{CH}_{2}$ & $111.9, \mathrm{CH}_{2}$ \\
\hline 20 & $15.8, \mathrm{CH}_{3}$ & $17.5, \mathrm{CH}_{3}$ & 17.6, $\mathrm{CH}_{3}$ \\
\hline$-\mathrm{OAc}$ & - & - & $20.9, \mathrm{CH}_{3}$ \\
\hline$-\mathrm{OAc}$ & - & - & $171.0, \mathrm{C}$ \\
\hline
\end{tabular}

Table 2. ${ }^{1} \mathrm{H}$ NMR data for compounds $\mathbf{1}-\mathbf{3}\left(\mathrm{CDCl}_{3}, 600 \mathrm{MHz}\right)$.

\begin{tabular}{|c|c|c|c|}
\hline No. & $1, \delta_{H}(J$ in $\mathrm{Hz})$ & $2, \delta_{H}(J$ in $\mathbf{H z})$ & $3, \delta_{H}(J$ in $\mathrm{Hz})$ \\
\hline \multirow[t]{2}{*}{1} & 3.36, ddd $(10.8,7.2,3.6)$ & $2.79, \mathrm{~m}$ & $2.81, \mathrm{~m}$ \\
\hline & $\mathrm{a}: 2.16, \mathrm{~m}$ & a: $2.33, \mathrm{~m}$ & \\
\hline 2 & $\begin{array}{c}\text { b: } 1.42, \text { ddd } \\
(14.4,10.2,3.6)\end{array}$ & $\mathrm{b}: 2.25, \mathrm{~m}$ & $2.41, \mathrm{~m}$ \\
\hline 3 & $2.58, \mathrm{dd}(10.2,1.2)$ & $5.16, \mathrm{t}(7.2)$ & $5.43, \mathrm{t}(7.2)$ \\
\hline \multirow{2}{*}{5} & a: $2.11, \mathrm{~m}$ & a: $2.24, \mathrm{~m}$ & $\mathrm{a}: 2.34, \mathrm{~m}$ \\
\hline & b: $1.14, \mathrm{~m}$ & $\mathrm{~b}: 2.10, \mathrm{~m}$ & $\mathrm{~b}: 2.22, \mathrm{~m}$ \\
\hline \multirow{2}{*}{6} & $\mathrm{a}: 2.16, \mathrm{~m}$ & a: $1.76, \mathrm{~m}$ & a: $1.77, \mathrm{~m}$ \\
\hline & b: $2.13, \mathrm{~m}$ & $\mathrm{~b}: 1.67, \mathrm{~m}$ & b: $1.73, \mathrm{~m}$ \\
\hline 7 & $4.95, \mathrm{dd}(7.2,1.8)$ & $4.35, \mathrm{dd}(7.8,4.2)$ & $4.35, \mathrm{dd}(8.4,4.8)$ \\
\hline \multirow{2}{*}{9} & $\mathrm{a}: 2.21, \mathrm{~m}$ & $\mathrm{a}: 2.34, \mathrm{~m}$ & $\mathrm{a}: 2.36, \mathrm{~m}$ \\
\hline & $\mathrm{b}: 2.06, \mathrm{~m}$ & b: $2.00, \mathrm{~m}$ & $\mathrm{~b}: 2.01, \mathrm{~m}$ \\
\hline \multirow{2}{*}{10} & $\mathrm{a}: 2.39, \mathrm{~m}$ & $\mathrm{a}: 2.33, \mathrm{~m}$ & a: $2.26, \mathrm{~m}$ \\
\hline & b: $2.10, \mathrm{~m}$ & b: $2.25, \mathrm{~m}$ & b: $2.24, \mathrm{~m}$ \\
\hline 11 & 5.11, br d $(9.0)$ & $5.23, \mathrm{t}(7.2)$ & $5.24, \mathrm{t}(7.2)$ \\
\hline \multirow{2}{*}{13} & a: 2.44, br d (14.4) & a: 2.47, dd $(14.4,4.8)$ & a: 2.49, dd $(13.8,4.2)$ \\
\hline & b: $2.38, \mathrm{dd}(14.4,10.8)$ & b: 2.07 , dd $(14.4,7.2)$ & b: 2.06, dd $(13.8,6.6)$ \\
\hline 14 & $4.97, \mathrm{~m}$ & $4.30, \mathrm{~m}$ & $4.33, \mathrm{~m}$ \\
\hline \multirow{2}{*}{17} & a: $6.26, \mathrm{~d}(2.4)$ & a: $6.28, \mathrm{~d}(2.4)$ & $\mathrm{a}: 6.30, \mathrm{~d}(2.4)$ \\
\hline & b: $5.52, \mathrm{~d}(2.4)$ & b: $5.63, \mathrm{~d}(2.4)$ & b: $5.67, \mathrm{~d}(2.4)$ \\
\hline 18 & $1.27, \mathrm{~s}$ & $1.66, \mathrm{~s}$ & $4.62, \mathrm{~s}$ \\
\hline \multirow{2}{*}{19} & \multirow{2}{*}{$1.62, \mathrm{~s}$} & a: 5.13 , br s & a: 5.13 , br s \\
\hline & & b: 5.08 , br s & b: 5.09, br s \\
\hline 20 & $1.74, \mathrm{~s}$ & $1.67, \mathrm{~s}$ & $1.68, \mathrm{~s}$ \\
\hline$-\mathrm{OAc}$ & - & - & $2.09, \mathrm{~s}$ \\
\hline$-\mathrm{OOH}$ & - & 7.78, br s & 7.92 , br s \\
\hline
\end{tabular}


Figure 2. COSY and HMBC correlations of compounds 1-3.
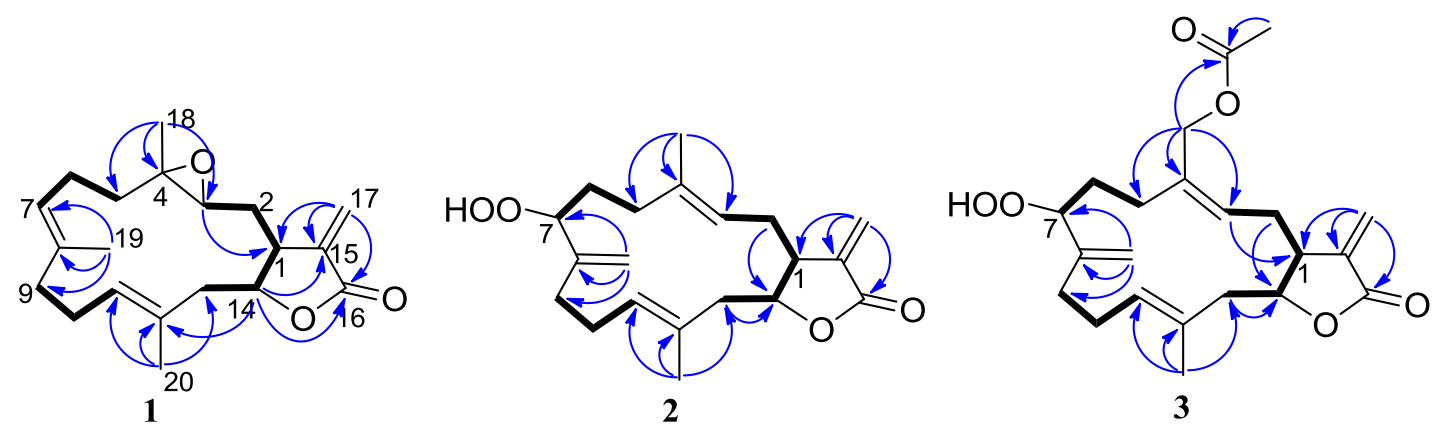

$\sim:{ }^{1} \mathrm{H}-{ }^{1} \mathrm{H}$ COSY correlations
$\curvearrowright: \mathrm{HMBC}$ correlations

Figure 3. Key NOE correlations and computer-generated models using MM2 force field calculations for compounds $\mathbf{1}$ and $\mathbf{2}$.

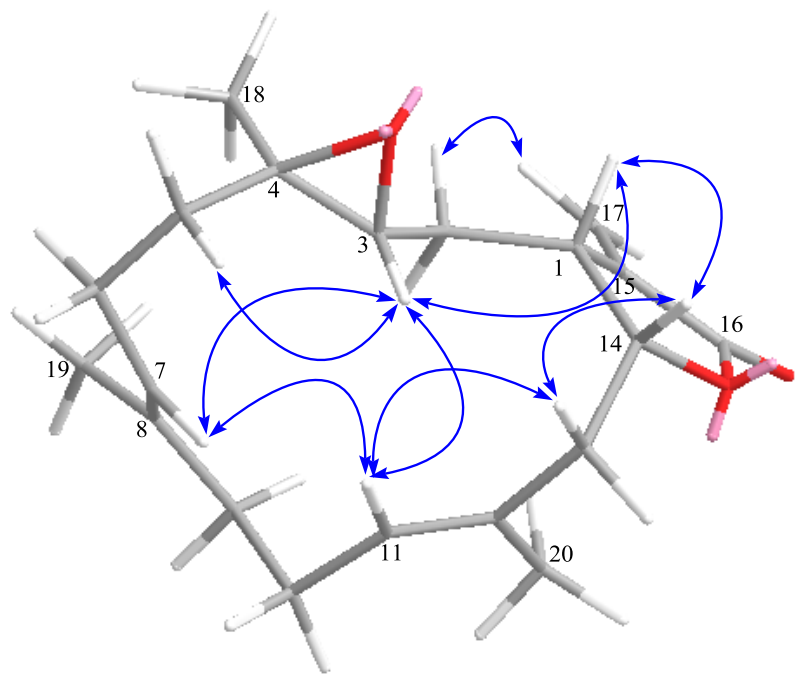

(1)

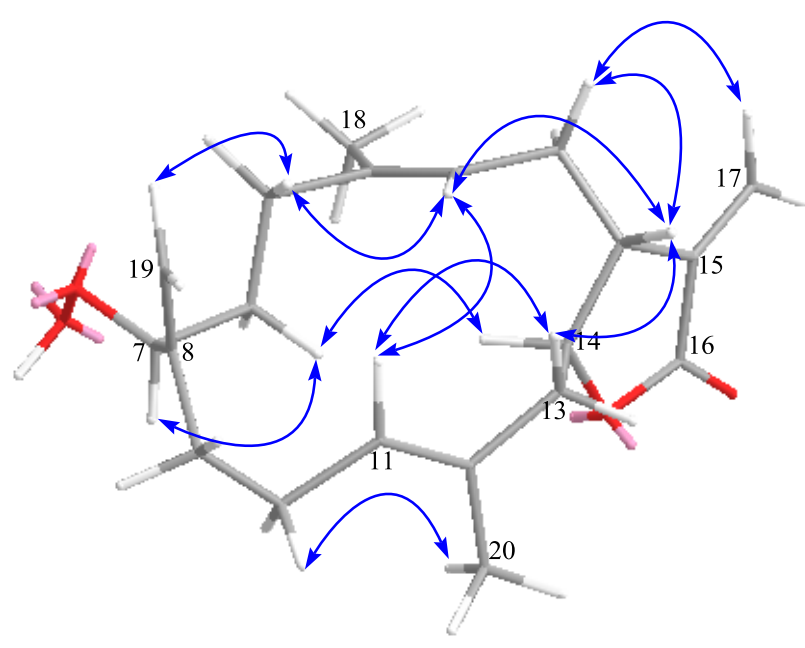

(2)

Compound $\mathbf{2}$ was also obtained as a colorless oil. The molecular formula of $\mathbf{2}$ was determined to be $\mathrm{C}_{20} \mathrm{H}_{28} \mathrm{O}_{4}$ on the basis of HRESIMS data $\left(m / z 355.1876[\mathrm{M}+\mathrm{Na}]^{+}\right.$, Calcd. 355.1880), implying seven degrees of unsaturation. Analysis of the ${ }^{1} \mathrm{H}$ and ${ }^{13} \mathrm{C}$ NMR spectra of 2 clearly revealed the presence of an $\alpha$-methylene- $\gamma$-lactone moiety [ $\delta_{\mathrm{H}} 6.28(1 \mathrm{H}, \mathrm{d}, J=2.4 \mathrm{~Hz}, \mathrm{H}-17 \mathrm{a}), 5.63(1 \mathrm{H}, \mathrm{d}, J=2.4 \mathrm{~Hz}, \mathrm{H}-17 \mathrm{~b})$; $\delta_{\mathrm{C}} 170.2(\mathrm{C}, \mathrm{C}-16), 139.2(\mathrm{C}, \mathrm{C}-15), 121.9\left(\mathrm{CH}_{2}, \mathrm{C}-17\right), 81.7(\mathrm{CH}, \mathrm{C}-14)$, and $\left.45.1(\mathrm{CH}, \mathrm{C}-1)\right]$, two trisubstituted double bonds $\left[\delta_{\mathrm{H}} 5.23(1 \mathrm{H}, \mathrm{t}, J=7.2 \mathrm{~Hz}, \mathrm{H}-11), 5.16(1 \mathrm{H}, \mathrm{t}, J=7.2 \mathrm{~Hz}, \mathrm{H}-3) ; \delta_{\mathrm{C}} 137.2\right.$ (C, C-4), $131.3(\mathrm{C}, \mathrm{C}-12), 128.0(\mathrm{CH}, \mathrm{C}-11)$, and $121.1(\mathrm{CH}, \mathrm{C}-3)]$, an additional exocyclic double bond $\left[\delta_{\mathrm{H}} 5.13\left(1 \mathrm{H}\right.\right.$, br s, H-19a), $5.08\left(1 \mathrm{H}\right.$, br s, H-19b); $\left.\delta_{\mathrm{C}} 149.2(\mathrm{C}, \mathrm{C}-8), 111.6\left(\mathrm{CH}_{2}, \mathrm{C}-19\right)\right]$, and two olefinic methyls [ $\left.\delta_{\mathrm{H}} 1.67\left(3 \mathrm{H}, \mathrm{s}, \mathrm{H}_{3}-20\right), 1.66\left(3 \mathrm{H}, \mathrm{s}, \mathrm{H}_{3}-18\right) ; \delta_{\mathrm{C}} 17.5\left(\mathrm{CH}_{3}, \mathrm{C}-20\right), 16.3\left(\mathrm{CH}_{3}, \mathrm{C}-18\right)\right]$. In addition, the presence of a hydroperoxyl group was disclosed by the NMR data at $\delta_{\mathrm{H}} 4.35(1 \mathrm{H}$, dd, $J=7.8,4.2 \mathrm{~Hz}, \mathrm{H}-7), 7.78(1 \mathrm{H}$, br s, $\mathrm{OOH})$ and $\delta_{\mathrm{C}} 84.5(\mathrm{CH}, \mathrm{C}-7)$, in association with the fact that two additional oxygen atoms remained in the molecule according to the HRESIMS data. All these data suggested that 2 possessed a cembrane skeleton with functionalities of an $\alpha$-methylene- $\gamma$-lactone, two methyl-bearing trisubstituted double bonds, an exocyclic double bond, and a secondary hydroperoxyl 
group. Further interpretation of ${ }^{1} \mathrm{H}-{ }^{1} \mathrm{H} \mathrm{COSY}$ and $\mathrm{HMBC}$ correlations established the gross structure of 2 as shown in Figure 2. The $E$ geometry of two double bonds at C-3/C-4 and C-11/C-12, and the trans junction of the $\alpha$-methylene- $\gamma$-lactone ring in $\mathbf{2}$ was determined based on the similar NMR data in comparison with those of the co-occurring analogue $\left(1 R^{*}, 14 S^{*}, 3 E, 7 E, 11 E\right)$-cembra-3,7,11,15 (17)-tetraen-16,14-olide (4) [21]. The configuration at C-7 was assigned by comparison of the ${ }^{13} \mathrm{C}$ NMR chemical shift of C-7 with that of decaryiol D, a cembrane diterpene containing the same partial structure extending from C-5 to C-13 [25]. In decaryiol D, the absolute configuration at C-7 was determined as $R$ unambiguously through structural transformation. While in compound $\mathbf{2}$, significant upfield shift of C-7 (-6.7 ppm) was observed, compared to decaryiol D, allowing the assignment of C-7 $S^{*}$ in 2. This assumption of stereochemistry for $\mathbf{2}$ was consistent with NOESY correlations (Figure 3), which indicated that $\mathrm{H}-1, \mathrm{H}-3, \mathrm{H}_{2}-19$, and $\mathrm{H}-11$ were located on the same side of the ring system, whereas H-7 and H-14 were oriented toward the opposite side. Thus, compound 2 was defined as $\left(1 R^{*}, 7 S^{*}, 14 S^{*}, 3 E, 11 E\right)$-7-hydroperoxycembra-3,8(19),11,15(17)-tetraen-16,14-olide.

Compound 3 had a molecular formula of $\mathrm{C}_{22} \mathrm{H}_{30} \mathrm{O}_{6}$ as determined by HRESIMS data $(\mathrm{m} / z$ 413.1925 $[\mathrm{M}+\mathrm{Na}]^{+}$, Calcd. 413.1934). The NMR spectroscopic data of compound 3 (Tables 1 and 2) indicated that it was an acetoxylated derivative of $\mathbf{2}$, as indicated by the presence of an acetoxyl group $\delta_{\mathrm{H}} 2.09$ $\left.(3 \mathrm{H}, \mathrm{s}) ; \delta_{\mathrm{C}} 171.0(\mathrm{C}), 20.9\left(\mathrm{CH}_{3}\right)\right]$ and an acetoxy-bearing methylene group $\left[\delta_{\mathrm{H}} 4.62\left(2 \mathrm{H}, \mathrm{s}, \mathrm{H}_{2}-18\right)\right.$; $\left.\delta_{\mathrm{C}} 61.9\left(\mathrm{CH}_{2}, \mathrm{C}-18\right)\right]$. The attachment of the acetoxyl group to $\mathrm{C}-18$ was revealed by the HMBC correlations from the acetoxy-bearing methylene protons $\left[\delta_{\mathrm{H}} 4.62\left(2 \mathrm{H}, \mathrm{s}, \mathrm{H}_{2}-18\right)\right]$ to the carbonyl carbon resonating at $\delta_{\mathrm{C}} 171.0(\mathrm{C})$, two olefinic carbons C-3 and C-4 [ $\delta_{\mathrm{C}} 127.4(\mathrm{CH})$ and $135.9(\mathrm{C})$, respectively], and an aliphatic methylene carbon $C-5\left(\delta_{C} 30.6\right)$. The relative stereochemistry of 3 was in agreement with that of $\mathbf{2}$ based on the similar NMR and NOE data. Thus, compound $\mathbf{3}$ was established as $\left(1 R^{*}, 7 S^{*}, 14 S^{*}, 3 E, 11 E\right)$-18-acetoxy-7-hydroperoxycembra-3,8(19),11,15(17)-tetraen-16,14-olide.

Compounds 1-3 were tested for their cytotoxicity against a panel of tumor cell lines including SGC7901 (human gastric carcinoma), A549 (human lung epithelial carcinoma), MCF7 (human breast carcinoma), HCT116 (human colonic carcinoma), and B16 (mouse melanoma). The bioassay results showed that compounds 1-3 possess moderate cytotoxicity against the selected tumor cell lines (Table 3 ).

Table 3. Cytotoxicity data of compounds 1-3.

\begin{tabular}{cccccc}
\hline \multirow{2}{*}{ Compounds } & \multicolumn{5}{c}{ IC $_{\mathbf{5 0}}(\boldsymbol{\mu g} / \mathbf{m L})$} \\
\cline { 2 - 6 } & SGC7901 & $\mathbf{A 5 4 9}$ & MCF7 & HCT116 & B16 \\
\hline $\mathbf{1}$ & 5.3 & 6.1 & 3.8 & 5.2 & 8.6 \\
$\mathbf{2}$ & 2.7 & 3.2 & 1.2 & 4.5 & 2.1 \\
$\mathbf{3}$ & 2.3 & 1.8 & 2.9 & 3.4 & 5.6 \\
\hline
\end{tabular}

In addition, all compounds were evaluated for the antimicrobial activity against Staphylococcus aureus, S. pneumoniae, Pseudomonas aerugonisa, Saccharomyces cerevisiae, and Aspergillus fumigatus. The antibiotic assay revealed that compounds $\mathbf{2}$ and $\mathbf{3}$ exhibited moderate inhibition against Staphylococcus aureus and S. pneumoniae with the inhibitory rates around $90 \%$ at $20 \mu \mathrm{g} / \mathrm{mL}$, but the other compounds were weak inhibitors against the two bacterial strains. All compounds showed weak effects against the microorganisms Pseudomonas aerugonisa, Saccharomyces cerevisiae, and Aspergillus fumigatus. 


\section{Experimental Section}

\subsection{General Experimental Procedures}

Optical rotations were determined with a PoLAAR 3005 digital polarimeter. IR spectra were obtained on a Bruker Equinox 55 spectrometer. ${ }^{1} \mathrm{H}$ and ${ }^{13} \mathrm{C}$ NMR and $2 \mathrm{D}$ NMR were recorded on a Bruker Avance $600 \mathrm{MHz}$ NMR spectrometer using TMS as an internal standard. Chemical shifts $(\delta)$ were expressed in parts per million (ppm), and coupling constants $(J$ ) were reported in Hertz (Hz). HRESIMS data were recorded by a Thermo Scientific Q Exactive hybrid quadrupole-Orbitrap mass spectrometer. Silica gel (200-300 mesh) for column chromatography and GF $_{254}$ silica gel for TLC was provided by Qingdao Marine Chemistry Co., Ltd. High-performance liquid chromatography (HPLC) chromatography was carried out using an Agilent 1100 series instrument equipped with a VWD G1314A detector at $210 \mathrm{~nm}$ and a YMC-Pack $\mathrm{C}_{18}(10 \mu \mathrm{m}, 250 \times 10 \mathrm{~mm})$ column.

\subsection{Animal Material}

The soft coral Lobophytum sp. was collected from the inner coral reef at a depth of $8 \mathrm{~m}$ in Sanya Bay, Hainan Island of China, in November 2011, and the fresh samples were frozen immediately after collection. The specimen was identified by Dr. Xiu-Bao Li (South China Sea Institute of Oceanology, CAS, Guangzhou, China). A voucher specimen (HS201105) is deposited at the Institute of Natural Drugs Development, Wenzhou Medical College, China.

\subsection{Extraction and Isolation}

The frozen soft coral Lobophytum sp. $(1.8 \mathrm{~kg})$ was homogenized and then extracted with $95 \% \mathrm{EtOH}$ $(4 \times 3 \mathrm{~L})$ at room temperature. The EtOH extract $(116.9 \mathrm{~g})$ was partitioned between $\mathrm{H}_{2} \mathrm{O}$ and EtOAc. The EtOAc fraction (21.9 g) was subjected to silica gel (200-300 mesh) column chromatography, and was eluted with a gradient of petroleum ether (PE)/EtOAc $(10: 1,5: 1,2: 1,1: 1)$ to obtain seven fractions (F1-F7). F3 (0.5 g) was fractioned on Sephadex LH-20 $\left(70 \times 2.5 \mathrm{~cm}\right.$, eluted with $\left.\mathrm{CH}_{2} \mathrm{Cl}_{2} / \mathrm{MeOH} 1: 1\right)$ to afford four subfractions (F3A-F3D). The subfraction F3C (73 mg) was further separated on reversed-phase semi-preparative $\mathrm{HPLC}$ with $\mathrm{MeOH} / \mathrm{H}_{2} \mathrm{O}$ (95:5) as a mobile phase to obtain 4 (18.8 $\mathrm{mg}$ ) and 14 (3.0 mg). F5 (3.7 g) was subjected to silica gel (200-300 mesh) column eluting with $\mathrm{PE} / \mathrm{CH}_{2} \mathrm{Cl}_{2}$ $(1: 1)$ to afford six subfractions (F5A-F5F). The subfraction F5C (324.6 mg) was separated on silica gel (200-300 mesh) column eluting with PE/Acetone (10:1), and further purified by an ODS column $\left(\mathrm{C}_{18}, 25 \times 2 \mathrm{~cm}\right.$, eluted with $\left.\mathrm{MeOH} / \mathrm{H}_{2} \mathrm{O} 85: 15\right)$ to obtain $12(20.0 \mathrm{mg})$. The subfraction F5E $(1.1 \mathrm{~g})$ was subjected to Sephadex LH-20 column eluting with $\mathrm{CH}_{2} \mathrm{Cl}_{2} / \mathrm{MeOH}(1: 1)$, and further purified by HPLC (MeOH/ $\left.\mathrm{H}_{2} \mathrm{O}, 80: 20\right)$ to afford 1 (4.9 mg), 2 (2.3 mg), 3 (5.8 mg), 8 (14.9 mg), 9 (21.2 mg), and 13 (6.2 mg). F6 (5.1 g) was separated on silica gel (200-300 mesh) column, eluted with $\mathrm{CH}_{2} \mathrm{Cl}_{2} / \mathrm{EtOAc}$ (30:1) to afford four subfractions (F6A-F6D). The subfraction F6B $(0.9 \mathrm{~g})$ was subjected to ODS column $\left(\mathrm{C}_{18}, 25 \times 2 \mathrm{~cm}\right.$, eluted with $\left.\mathrm{MeOH} / \mathrm{H}_{2} \mathrm{O} 80: 20\right)$, and further purified by $\mathrm{HPLC}\left(\mathrm{MeOH} / \mathrm{H}_{2} \mathrm{O}\right.$, 80:20) to afford 11 (14.2 mg), 5 (10.0 mg), 6 (9.6 mg), and 7 (10.6 mg). Compound 10 (16.9 mg) was obtained from $\mathrm{F} 6 \mathrm{C}(0.5 \mathrm{~g})$ by the same separation process as that for $\mathrm{F} 6 \mathrm{~B}$. 
$\left(1 R^{*}, 3 R^{*}, 4 R^{*}, 14 R^{*}, 7 E, 11 E\right)-3,4$-epoxycembra-7,11,15(17)-trien-16,14-olide (1), obtained as colorless oil; $[\alpha]_{\mathrm{D}}{ }^{25}+133.4\left(c 0.17, \mathrm{CHCl}_{3}\right)$; IR (KBr) $v_{\max } 2903,1759,1660,1441,1342,1270,1155,1123$, $994 \mathrm{~cm}^{-1} ;{ }^{1} \mathrm{H}$ and ${ }^{13} \mathrm{C}$ NMR data, see Tables 1 and 2; HRESIMS $(\mathrm{m} / z) 317.2105[\mathrm{M}+\mathrm{H}]^{+}(\mathrm{Calcd}$. for $\left.\mathrm{C}_{20} \mathrm{H}_{29} \mathrm{O}_{3}, 317.2111\right)$.

$\left(1 R^{*}, 7 S^{*}, 14 S^{*}, 3 E, 11 E\right)$-7-hydroperoxycembra-3,8(19),11,15(17)-tetraen-16,14-olide (2), obtained as colorless oil; $[\alpha]_{\mathrm{D}}{ }^{25}+150.9\left(c 0.14, \mathrm{CHCl}_{3}\right)$; IR ( $\left.\mathrm{KBr}\right) v_{\max } 3411,2962,2930,2865,1762,1659,1643$, 1272, 1169, $1080 \mathrm{~cm}^{-1} ;{ }^{1} \mathrm{H}$ and ${ }^{13} \mathrm{C}$ NMR data, see Tables 1 and 2 ; HRESIMS $(\mathrm{m} / \mathrm{z}) 355.1876[\mathrm{M}+\mathrm{Na}]^{+}$ (Calcd. for $\mathrm{C}_{20} \mathrm{H}_{28} \mathrm{O}_{4} \mathrm{Na}, 355.1880$ ).

$\left(1 R^{*}, 7 S^{*}, 14 S^{*}, 3 E, 11 E\right)$-18-acetoxy-7-hydroperoxycembra-3,8(19),11,15(17)-tetraen-16,14-olide (3), obtained as colorless oil; $[\alpha]_{\mathrm{D}}{ }^{25}+214.4\left(c 0.10, \mathrm{CHCl}_{3}\right)$; IR $(\mathrm{KBr}) v_{\max } 3420,2964,2925,2863,1760$, 1745, 1660, 1235, $1095 \mathrm{~cm}^{-1} ;{ }^{1} \mathrm{H}$ and ${ }^{13} \mathrm{C}$ NMR data, see Tables 1 and 2; HRESIMS $(\mathrm{m} / \mathrm{z}) 413.1925$ $[\mathrm{M}+\mathrm{Na}]^{+}$(Calcd. for $\left.\mathrm{C}_{22} \mathrm{H}_{30} \mathrm{O}_{6} \mathrm{Na}, 413.1934\right)$.

\subsection{Cytotoxicity Assay}

The cytotoxic properties of the isolated compounds were tested in vitro using tumor cell lines including SGC7901 (human gastric carcinoma), A549 (human lung epithelial carcinoma), MCF7 (human breast carcinoma), HCT116 (human colonic carcinoma), and B16 (mouse melanoma) tumor cells by a modification of the MTT colorimetric method according to a previously described procedure [26,27]. The cell lines were purchased from the Cell Resource Center of Shanghai Institute of Biological Sciences, CAS.

\subsection{Antibiotic Assay}

Antimicrobial bioassays were conducted in triplicate according to the method recommended by the National Center for Clinical Laboratory Standards (NCCLS) [28]. The bacterial strains Staphylococcus aureus, S. pneumoniae, and Pseudomonas aerugonisa were grown on Mueller-Hinton agar. The yeast, Saccharomyces cerevisiae, was grown on Sabouraud dextrose agar, and the fungus, Aspergillus fumigatus, was grown on potato dextrose agar. Targeted microbes (3-4 colonies) were prepared from broth culture (bacteria: $37^{\circ} \mathrm{C}$ for $24 \mathrm{~h}$; fungus: $28^{\circ} \mathrm{C}$ for $48 \mathrm{~h}$ ), and the final spore suspensions of bacteria (in MHB medium), yeast (in SDB medium), and fungus (in PDB medium) were $10^{6}$ and $10^{5}$ cells $/ \mathrm{mL}$ and $10^{4}$ mycelial fragments $/ \mathrm{mL}$, respectively. Testing compounds $(10 \mathrm{mg} / \mathrm{mL}$ as stock solution in DMSO and serial dilutions) were transferred to a 96-well clear plate in triplicate, and the suspension of the test microorganisms were added to each well $(200 \mu \mathrm{L})$ (antimicrobial peptide AMP, streptomycin, and fluconazole were used as positive controls). After incubation, the absorbance at $595 \mathrm{~nm}$ was measured with a microplate reader (TECANT), and the inhibition rate was calculated and plotted versus test concentrations.

\section{Conclusions}

Three new $\alpha$-methylene- $\gamma$-lactone-containing cembranoids, namely $\left(1 R^{*}, 3 R^{*}, 4 R^{*}, 14 R^{*}, 7 E, 11 E\right)-3$, 4-epoxycembra-7,11,15(17)-trien-16,14-olide (1), (1 $\left.R^{*}, 7 S^{*}, 14 S^{*}, 3 E, 11 E\right)$-7-hydroperoxycembra-3,8 (19),11,15(17)-tetraen-16,14-olide (2), and $\left(1 R^{*}, 7 S^{*}, 14 S^{*}, 3 E, 11 E\right)$-18-acetoxy-7-hydroperoxycembra-3, 
8(19),11,15(17)-tetraen-16,14-olide (3), along with eleven known analogues 4-14, were isolated from the South China Sea soft coral Lobophytum sp. Compounds $\mathbf{2}$ and $\mathbf{3}$ contain a rare hydroperoxyl group at C-7. The isolation of compounds 1-3 constitutes a new addition to the molecular diversity of cembrane-type diterpenoids. In addition, compounds 1-3 were found to show moderate cytotoxic activity against the selected tumor cell lines including SGC7901 (human gastric carcinoma), A549 (human lung epithelial carcinoma), MCF7 (human breast carcinoma), HCT116 (human colonic carcinoma), and B16 (mouse melanoma) with $\mathrm{IC}_{50}$ values ranged from 1.2 to $8.6 \mu \mathrm{g} / \mathrm{mL}$. Compounds 2 and $\mathbf{3}$ displayed moderate inhibition against the bacteria $S$. aureus and $S$. pneumoniae with inhibitory rates of around $90 \%$ at $20 \mu \mathrm{g} / \mathrm{mL}$, suggesting them to be promising lead structures for antibiotics. Further studies should be conducted to elucidate the antibacterial mechanism of $\mathbf{2}$ and $\mathbf{3}$, as well as to understand the ecological roles of these metabolites in the life cycle of the soft coral.

\section{Acknowledgments}

This research was supported by grant from the NSFC (No. 21202123) and Start-Up Funding from Wenzhou Medical College (No. QTJ10018).

\section{Conflict of Interest}

The authors declare no conflict of interest.

\section{References}

1. Bonnard, I.; Jhaumeer-Laulloo, S.B.; Bontemps, N.; Banaigs, B.; Aknin, M. New lobane and cembrane diterpenes from two Comorian soft corals. Mar. Drugs 2010, 8, 359-372.

2. Wanzola, M.; Furuta, T.; Kohno, Y.; Fukumitsu, S.; Yasukochi, S.; Watari, K.; Tanaka, C.; Higuchi, R.; Miyamoto, T. Four new cembrane diterpenes isolated from an Okinawan soft coral Lobophytum crassum with inhibitory effects on nitric oxide production. Chem. Pharm. Bull. 2010, $58,1203-1209$.

3. Cheng, S.Y.; Wen, Z.H.; Chiou, S.F.; Hsu, C.H.; Wang, S.K.; Dai, C.F.; Chiang, M.Y.; Duh, C.Y. Durumolides A-E, anti-inflammatory and antibacterial cembranolides from the soft coral Lobophytum durum. Tetrahedron 2008, 64, 9698-9704.

4. Zhang, W.; Krohn, K.; Ding, J.; Miao, Z.H.; Zhou, X.H.; Chen, S.H.; Pescitelli, G.; Salvadori, P.; Kurtan, T.; Guo, Y.W. Structural and stereochemical studies of $\alpha$-methylene- $\gamma$-lactone-bearing cembrane diterpenoids from a South China Sea soft coral Lobophytum crassum. J. Nat. Prod. 2008, 71, 961-966.

5. Chao, C.H.; Wen, Z.H.; Wu, Y.C.; Yeh, H.C.; Sheu, J.H. Cytotoxic and anti-inflammatory cembranoids from the soft coral Lobophytum crassum. J. Nat. Prod. 2008, 71, 1819-1824.

6. Chen, S.H.; Huang, H.; Guo, Y.W. Four new cembrane diterpenes from the Hainan soft coral Lobophytum sp. Chin. J. Chem. 2008, 26, 2223-2227.

7. Tseng, Y.J.; Wen, Z.H.; Hsu, C.H.; Dai, C.F.; Sheu, J.H. Bioactive cembranoids from the Dongsha Atoll soft coral Lobophytum crassum. Bull. Chem. Soc. Jpn. 2011, 84, 1102-1106. 
8. Quang, T.H.; Ha, T.T.; Minh, C.V.; Kiem, P.V.; Huong, H.T.; Ngan, N.T.T.; Nhiem, N.X.; Tung, N.H.; Tai, B.H.; Thuy, D.T.T.; et al. Cytotoxic and anti-inflammatory cembranoids from the Vietnamese soft coral Lobophytum laevigatum. Bioorg. Med. Chem. 2011, 19, 2625-2632.

9. Hong, J.Y.; Boo, H.J.; Kang, J.I.; Kim, M.K.; Yoo, E.S.; Hyun, J.W.; Koh, Y.S.; Kim, G.Y.; Maeng, Y.H.; Hyun, C.L.; et al. (1S,2S,3E,7E,11E)-3,7,11,15-cembratetraen-17,2-olide, a cembrenolide diterpene from soft coral Lobophytum sp., inhibits growth and induces apoptosis in human colon cancer cells through reactive oxygen species generation. Biol. Pharm. Bull. 2012, 35, 1054-1063.

10. Cheng, S.Y.; Chen, P.W.; Chen, H.P.; Wang, S.K.; Duh, C.Y. New cembranolides from the Dongsha Atoll soft coral Lobophytum durum. Mar. Drugs 2011, 9, 1307-1318.

11. Lin, S.T.; Wang, S.K.; Duh, C.Y. Cembranoids from the Dongsha Atoll soft coral Lobophytum crassum. Mar. Drugs 2011, 9, 2705-2716.

12. Hegazy, M.E.F.; Su, J.H.; Sung, P.J.; Sheu, J.H. Cembranoids with 3,14-ether linkage and a secocembrane with bistetrahydrofuran from the Dongsha Atoll soft coral Lobophytum sp. Mar. Drugs 2011, 9, 1243-1253.

13. Kao, C.Y.; Su, J.H.; Lu, M.C.; Hwang, T.L.; Wang, W.H.; Chen, J.J.; Sheu, J.H.; Kuo, Y.H.; Weng, C.F.; Fang, L.S.; et al. Lobocrassins A-E: New cembrane-type diterpenoids from the soft coral Lobophytum crassum. Mar. Drugs 2011, 9, 1319-1331.

14. Wang, S.K.; Duh, C.Y. New cytotoxic cembranolides from the soft coral Lobophytum michaelae. Mar. Drugs 2012, 10, 306-318.

15. Yamada, K.; Ryu, K.; Miyamoto, T.; Higuchi, R. Bioactive terpenoids from octocorallia. 4. Three new cembrane-type diterpenoids from the soft coral Lobophytum schoedei. J. Nat. Prod. 1997, 60, 798-801.

16. Uchio, Y.; Eguchi, S.; Kuramoto, J.; Nakayama, M.; Hase, T. Denticulatolide, an ichthyotoxic peroxide-containing cembranolide from the soft coral Lobophytum denticulatum. Tetrahedron Lett. 1985, 26, 4487-4490.

17. Yan, P.; Lv, Y.; Ofwegen, L.V.; Proksch, P.; Lin, W. Lobophytones A-G, new isobiscembranoids from the soft coral Lobophytum pauciflorum. Org. Lett. 2010, 12, 2484-2487.

18. Yan, P.; Deng, Z.; Ofwegen, L.V.; Proksch, P.; Lin, W. Lobophytones H-N, biscembranoids from the Chinese soft coral Lobophytum pauciflorum. Chem. Pharm. Bull. 2010, 58, 1591-1595.

19. Yan, P.; Deng, Z.; Ofwegen, L.V.; Proksch, P.; Lin, W. Lobophytones O-T, new biscembranoids and cembranoid from soft coral Lobophytum pauciflorum. Mar. Drugs 2010, 8, 2837-2848.

20. Yan, P.; Deng, Z.; Ofwegen, L.V.; Proksch, P.; Lin, W. Lobophytones U-Z 1 , biscembranoids from the Chinese soft coral Lobophytum pauciflorum. Chem. Biodivers. 2011, 8, 1724-1734.

21. Ahond, A.; Bowden, B.F.; Coll, J.C.; Fourneron, J.-D.; Mitchell, S.J. Studies of Australian soft corals. XII. Further cembranolide diterpenes from Lobophytum crassospiculatum and a correction of a previous stereochemical assignment. Aust. J. Chem. 1979, 32, 1273-1280.

22. Chen, S.H.; Guo, Y.W.; Huang, H.; Cimino, G. Six new cembranolides from the Hainan soft coral Lobophytum sp. Helv. Chim. Acta 2008, 91, 873-880.

23. Kashman, Y.; Carmely, S.; Groweiss, A. Further cembranoid derivatives from the Red Sea soft corals Alcyonium flaccidum and Lobophytum crassum. J. Org. Chem. 1981, 46, 3592-3596. 
24. Huang, H.C.; Ahmed, A.F.; Su, J.H.; Chao, C.H.; Wu, Y.C.; Chiang, M.Y.; Sheu, J.H. Crassocolides A-F, cembranoids with a trans-fused lactone from the soft coral Sarcophyton crassocaule. J. Nat. Prod. 2006, 71, 1554-1559.

25. Fattorusso, E.; Romano, A.; Taglialatela-Scafati, O.; Irace, C.; Maffettone, C.; Bavestrello, G.; Cerrano, C. Oxygenated cembranoids of the decaryiol type from the Indonesian soft coral Lobophytum sp. Tetrahedron 2009, 65, 2898-2904.

26. Geran, R.I.; Greenberg, N.H.; MacDonald, M.M.; Schumacher, A.M.; Abbott, B.J. Protocols for screening chemical agents and natural products against animal tumors and other biological systems. Cancer Chemother. Rep. 1972, 3, 1-91.

27. Hou, R.S.; Duh, C.Y.; Chiang, M.Y.; Lin, C.N. Sinugibberol, a new cytotoxic cembranoid diterpene from the soft coral Sinularia gibberosa. J. Nat. Prod. 1995, 58, 1126-1130.

28. Li, E.; Jiang, L.; Guo, L.; Zhang, H.; Che, Y. Pestalachlorides A-C, antifungal metabolites from the plant endophytic fungus Pestalotiopsis adusta. Bioorg. Med. Chem. 2008, 16, 7894-7899.

Samples Availability: Available from the authors.

(C) 2013 by the authors; licensee MDPI, Basel, Switzerland. This article is an open access article distributed under the terms and conditions of the Creative Commons Attribution license (http://creativecommons.org/licenses/by/3.0/). 